\title{
Studi Konstruksi Makna Hubungan Antarumat Beragama Dengan Pendekatan Model (Coordinated Management of Meaning-CMM)
}

\author{
Nurma Yuwita ${ }^{1 *}$, Darsono Wisadirana ${ }^{2}$, Suryadi $^{3}$ \\ ${ }^{1}$ Mahasiswa progam studi Magister Ilmu Komunikasi, FISIP, Universitas Brawijaya, Malang, Indonesia \\ ${ }^{2}$ Dekan FISIP, Dosen IImu Komunikasi, Fakultas IImu Sosial dan IImu Politik, Universitas Brawijaya \\ ${ }^{3}$ Dosen Ilmu Komunikasi, Fakultas IImu Sosial dan Ilmu Politik, Universitas Brawijaya
}

\begin{abstract}
Abstrak
Penelitian ini berangkat dari studi Coordinated Management of Meaning (CMM) dalam mengkonstruksi makna hubungan antarumat beragama perspektif Kiai Sholeh. Penelitian ini menggunakan pendekatan interpretatifkonstruktivis. Metodologi yang digunakan kualitatif deskriptif dengan metode pengambilan sampel purposive sampling. Metode dalam pengumpulan data yaitu wawancara mendalam, observasi dan dokumentasi. Penelitian ini menghasilkan teori Coordinated Management of Meaning (CMM) dalam konteks hubungan antarumat beragama. Makna hubungan antarumat beragama perspektif Kiai Sholeh adalah Tuhan menciptakan manusia berbeda-beda agar mereka bisa saling belajar, bergaul, dan membantu antara satu dan lainnya dan mengakui perbedaan-perbedaan itu sebagai sebuah realitas. Kiai Sholeh mewujudkan konsep hubungan antarumat beragama dengan formasi dialog. Interpretasi dari dialog adalah interaksi Kiai Sholeh dengan non muslim seperti doa bersama, silaturrahmi keagamaan, pentas seni, live in, kerja sama bidang pendidikan, peleburan budaya antarumat beragama, dan aksi sosial pemuda bangsa. Hubungan yang sudah dijalankan oleh Kiai Sholeh dengan non muslim sebatas hubungan dhohir dan duniawi bukan hubungan ukhrowi. Kiai Sholeh menerapkan konsep hubungan antarumat beragama dipengaruhi oleh ayahnya sendiri Kiai Bahruddin dan gurunya Kiai Munawir serta pemahaman Kiai Sholeh terhadap piagam madinah. Pola budaya yang telah diterapkan oleh Kiai Sholeh dalam hubungan antarumat beragama adalah konsep tasawuf dan thoriqoh.
\end{abstract}

Kata kunci: CMM, Konstruksi Makna, Hubungan Antarumat Beragama

\section{Abstract}

This research departs from the study Coordinated Management of Meaning (CMM) in the construction meaning of relationships among religious perspective Kiai Sholeh. This research uses interpretive-constructivist approach. The methodology used qualitative descriptive with purposive sampling method. The method of collecting the data is namely in-depth interviews, observation and documentation. This research resulted in the theory of Coordinated Management of Meaning (CMM) in the context of inter-religious relations. The Meaning of relationship interfaith perspective Kiai Sholeh is God create humans differently, so that they can learn from each other, hang out, and help from each other and recognize the differences as a reality. Kiai Sholeh realize the concept of interfaith relations with the formation of the dialogue. Interpretation of the dialogue is Kiai Sholeh's interaction with non-Muslims such as joint prayer, religious silaturrahmi (friendship), performing arts, live in, cooperation in education, interfaith culture smelting, and social action of the youth of the nation. Relationships that have been run by Kiai Sholeh limited in relations with non-Muslims and secular Dhohir (body) not ukhrowi (spiritual) relationship. Kiai Sholeh apply the concept of interfaith relationship are influenced by his father and his teacher, Kiai Bahruddin and Kiai Munawir as well as an understanding of the charter of the medina. Cultural patterns that have been implemented by Kiai Sholeh in interfaith relations is the concept of Sufism and thoriqoh.

Keywords: CMM, Construction Meaning, and Relationship Among the Religious.

\section{PENDAHULUAN}

Coordinated Management of Meaning (CMM) berfokus pada diri dan hubungannya dengan orang lain, serta interpretasi makna pada sebuah pesan [1]. CMM telah diposisikan sebagai teori umum komunikasi sejak dicetuskan pada akhir tahun 1970-an. Teori komunikasi CMM

Alamat Korespondensi Penulis:

Nurma Yuwita

Email : yuwita.nurma@gmail.com

Alamat : Grogolan Rt/Rw: 01/02 Winong Gempol

Pasuruan 67155 berkembang dari waktu ke waktu sebagai teori interpretif sebagai teori kritis dan yang terbaru sebagai teori praktis. Teori praktis berkembang dari ide bahwa CMM adalah teori praktis dan menyediakan kerangka komprehensif untuk mengatur hubungan antar fenomena [2]. 
CMM telah menawarkan beberpa alternatif yang berbeda seperti membuat kehidupan masyarakat lebih baik mulai dari peningkatan koordinasi, pembebasan, komunikasi kosmopolitan [2]. Banyak studi kasus yang telah dihasilkan oleh konsep CMM dan digunakan untuk mengembangkan intervensi terapeutik yang dapat membantu klien untuk melarutkan masalah mereka dan bergerak maju. Penelitian yang dilakukan oleh Jasmine E. Tan, Ph.D. menjelaskan tentang Gender dan CMM terhadap persepsi keuangan wanita dengan menggunakan sudut pandang feminisme dan teori CMM sebagai dasar teoritis untuk mengeksplorasi cara-cara perempuan membuat dan menjaga arti keuangan dalam pengalaman hidup mereka [3]. Penelitian tersebut menawarkan beberapa implikasi praktis untuk pendidik keuangan, industri pemasaran keuangan dan program melek finansial.

Teori CMM berakar dari teori interaksionisme simbolik. Para tetua intelektual dari interaksionisme simbolik adalah ahli pragmatis pada awal abad 20, seperti John Dewey dan William James. Para ilmuwan pragmatis percaya bahwa realitas bersifat dinamis [1]. Menurut Littlejohn Interaksionisme simbolik pada awalnya terbagi dalam dua tradisi yaitu Chicago school dan lowa school [4]. Menurut West \& Turner Interaksi Simbolik lahir pada dua universitas yang berbeda yaitu University of lowa dan University of Chicago [1]. Kebanyakan prinsip interaksi simbolik dan pengembangannya berakar dari Mahzab Chicago. Mazhab Chicago yang dimotori oleh Herbert Blumer, melanjutkan tradisi humanistis yang dimulai oleh George Herbert Mead [5]. Menurut Mulyana mazhab yang populer digunakan adalah Mazhab Chicago [6].

Dalam penelitian CMM ini, peneliti menganalisis studi konstruksi makna hubungan antarumat beragama perspektif Kiai Sholeh dengan pendekatan model (Coordinated Management of Meaning-CMM). Kiai Sholeh merupakan salah satu penggerak hubungan antarumat beragama. Menurut Kiai Sholeh, pada dasarnya hubungan antarumat beragama adalah sebuah pengakuan akan hukum Tuhan yang menciptakan manusia yang tidak hanya terdiri dari satu kelompok, suku, warna kulit, dan agama saja. Tuhan menciptakan manusia berbeda-beda agar mereka bisa saling belajar, bergaul, dan membantu antara satu dan lainnya. Hubungan antarumat beragama mengakui perbedaanperbedaan itu sebagai sebuah realitas yang pasti ada dimana saja [7].
Peneliti mengkaji makna hubungan antarumat beragama dikarenakan Indonesia merupakan negara yang besar yang memiliki beragam etnis, ras, agama, aliran kepercayaan, bahasa, adat istiadat, orientasi kultur kedaerahan, serta pandangan hidup [8]. Menurut Riyadi \& Basuki bahwa kemajemukan bangsa Indonesia disebabkan hampir semua agama-agama besar, yakni Islam, Kristen Protestan, Katholik, Hindu, Budha dan Konghuchu. Disisi lain, masyarakat Indonesia juga terdiri dari beragam suku, etnis, budaya, dan bahasa. Bentuk negara kepulauan, juga menyebabkan penghayatan dan pengamalan keagamaan bangsa ini unik dibandingkan dengan bangsa-bangsa lain [9].

Konflik berbau kekerasan di Indonesia juga terjadi antara dua kelompok atau lebih dalam satu agama, khususnya Islam. Kasus penganiayaan terhadap kyai yang dilakukan Komando Laskar Islam (KLI) dan Front Pembela Islam (FPI) terhadap Aliansi Kebangsaan untuk Kebebasan Beragama dan Berkeyakinan (AKKBB) pada 1 Juni 2008. Organisasi yang mengatasnamakan agama sebagai ideologi melakukan tindakan anarkis dan kekerasan. Di Bogor muncul keputusan Jaksa Agung Hendarman Supanji yang menyakatan, aliran Satrio Piningit Weteng Buwono pimpinan Agus Imam Solihin adalah aliran menyimpang dan harus dilarang. Kemudian masyarakat Cileungsi bersama polisi melakukan sweeping terhadap pengikut aliran ini di Kampung Karet, Desa Situsari, Kecamatan Cileungsi, Kabupaten Bogor [10].

Kasus Lain tentang konflik agama yang terbaru adalah aliran Kristen saksi Yehuwa. Aliran ini mengadakan acara disebelah rumah makan Hotplate, dikelurahan Temas Kota Batu Malang. Aliran Kristen Saksi Yehuwa yang sampai hari ini dianggap aliran sempalan (sesat) oleh kaum Kristen sendiri, mereka hendak mendirikan Istana Tuhan (bukan gereja). Aliran ini juga tidak memasang salib atau simbol-simbol agama Kristen lainnya. Orang Kristen menganggap sesat kelompok ini, karena meyakini bahwa Isa bukanlah Tuhan/Yesus, tetapi utusan sama seperti umat Islam mempercayai Nabi Muhammad SAW sebagai utusan Allah. Jadi perjuangan kelompok ini lebih intensif ke komunitas Kristen dari pada kekomunitas Islam, sehingga ketika mereka akan mendirikan tempat ibadah ada dua penolakan yang dialami oleh kelompok Saksi Yehuwa, yakni dari kelompok Islam dan kelompok yang kedua dari masyarakat Islam [8]. 
Konflik agama juga terjadi di Australia yang melakukan serangan terhadap orang muslim. Dalam satu peristiwa seorang Ibu di Sydney Barat dan bayinya diludahi, dan kereta bayinya ditendang. Dalam kasus lain, seorang laki-laki di Perth berusaha menarik kerudung (jilbab) di kepala seorang perempuan. Beberapa masjid di Australia telah diancam, dilempari telur busuk, dirusak, dan dipasangi Salib yang dihias dengan kepala babi [11].

Konflik agama merupakan salah satu alat ampuh yang dapat memicu perpecahan. Sebagaimana dikemukakan oleh Sumbulah \& Nurjanah bahwasannya faktor penyebab konflik antar umat beragama baik dalam skala kecil maupun skala besar adalah karena faktor agama [8]. Budaya kekerasan yang dilandasi oleh motivasi dan keyakinan keragamaan agama sungguh sangat memprihatinkan, atas nama agama orang dengan mudah membunuh nyawa penganut agama lain, merusakkan rumah-rumah ibadah agama, dan dengan melakukan itu mereka beranggapan telah melakukan jihad fisabilillah (berjuang dijalan Allah). Agama tidak lagi menjadi rahmatal lil alamin (rahmat bagi seluruh alam) melainkan sudah menjadi sebuah laknatal lil alamin (lakanat bagi seluruh alam).

Padahal kehadiran agama dalam kehidupan umat manusia merupakan sebuah kebutuhan seperti halnya manusia hidup dan berjuang untuk mencari penghidupan serta peningkatan hidup. Agama lahir sesuai fitrah manusia dan beragama bagi umat manusia merupakan sebuah proses pengendapan nilai-nilai formal agama yang pada dasarnya bersifat fitri. Fitrah berarti selaras dengan potensi yang sudah dianugerahkan Tuhan pada diri manusia dan bukan merupakan sesuatu yang melampui esensinya. Akan tetapi dalam proses pencarian agama yang bersifat primordial, manusia diwarnai oleh kemajemukan dalam soal keyakinan (agama). Dan kemajemukan itu kerap kali menimbulkan berbagai gesekan dan ketegangan yang menguras air mata dan bahkan tumpahan darah [12].

Sebagian masyarakat kita cenderung sempit dalam memahami agama. Cara berfikir masyarakat tersebut cenderung tidak luwes dalam menghadapi tantangan-tantangan budaya yang semakin beragam. Mungkin perlu untuk merenungi kembali visi kehadiran agama yang mengajarkan perdamaian dan persaudaraan. Namun visi agama ini malah ternodai oleh bentuk budaya kekerasan yang semakin marak terjadi ditengah-tengah masyarakat kita. Dan yang lebih memprihatinkan lagi, fenomena ini secara langsung menyangkut kehidupan umat beragama. Seringkali ajaran agama dijadikan legitimasi atas tindak kekerasan [13].

Menyadari bahwa pluralisme masyarakat begitu tinggi sehingga mengakibatkan pada potensi konflik yang tiada hentinya. Banyak elitagama berusaha menyikapi pluralitas dengan konsep pluralisme. Salah satu elitagama yang menerapkan konsep pluralisme adalah KH Sholeh Bahruddin. Kiai Sholeh panggilan dari KH Sholeh Bahruddin adalah pemangku pondok pesantren "Ngalah" Purwosari Pasuruan. Kiai Sholeh adalah salah satu diantara kyai yang memperjuangkan konsep pluralisme agama. Kiai Sholeh dalam memperjuangkan pluralisme agama merangkul elitagama lain seperti Kristen, Katolik, Hindu, Budha dan Konghucu.

Perjuangan Kiai Sholeh untuk memperkokoh kesatuan antarumat beragama dilakukan dengan berbagai pola diantaranya mengadakan seminar nasional antarumat beragama dengan menghadirkan Ibu Sinta Nuriah (Istri Gus Dur), Kiai Said Aqil Siradj Ketua PBNU, Romo Beni dan para elitagama lain. Selain itu beliau juga menerbitkan beberapa buku yang berisikan tentang multikulturalisme dan pluralisme agama.

Semua fenomena itu menandakan bahwa Kiai Sholeh sangat menghormati dan menghargai perbedaan agama. Dari beberapa perilaku Kiai Sholeh yang mengandung nilai-nilai pluralistik berharap agar dapat menciptakan kerukunan hidup antar umat beragama.

Penelitian ini bertujuan untuk menganalisis konstruksi makna hubungan antarumat beragama perspektif Kiai Sholeh dengan pendekatan model (Coordinated Management of Meaning-CMM).

\section{METODE PENELITIAN}

Penelitian ini menggunakan pendekatan interpretif-kontruktivis dan metodologi kualitatif. Menurut Neuman Ilmu sosial Interpretif berkaitan dengan cara orang berinteraksi dan hidup akur satu sama lain [14]. Penelitian ini dilakukan di pondok pesantren Ngalah yang diasuh oleh Kiai sholeh tepatnya desa Pandean Purwosari Pasuruan dengan menggunakan dua macam informan, yaitu informan utama dan informan pendukung. Informan utama adalah Kiai Sholeh Bahruddin sebagai orang yang berusaha menjalin hubungan antarumat beragama. Metode pengambilan sampel yang digunakan adalah Non Probability Sampling dengan teknik pengambilan sampel purposive sampling. Menurut Kriyantono teknik purposif adalah menentukan orang berdasarkan kriteria, dimana kriteria harus 
mendukung tujuan penelitian [15]. Kriteria informan utama dalam penelitian ini antara lain:

a) Penggagas hubungan antarumat beragama;

b) Pernah mengadakan kegiatan yang bersifat pluralistik;

c) Pernah menyelenggarakan forum komunikasi antarumat beragama;

d) Pernah mengenyam dan menyelesaikan pendidikan sebagai santri .

Informan selanjutnya adalah informan pendukung yang memiliki pemahaman atas informasi yang dibutuhkan serta dapat melengkapi dan memperkuat informasi dari informan utama. Informan pendukung dalam penelitian ini adalah santri. Untuk santri dipilih dengan kriteria :

a) Santri pondok pesantren Ngalah;

b) Pernah terlibat membantu kiai secara langsung menyelenggarakan kegiatan yang bersifat pluralistik;

c) Pernah terlibat membantu Kiai Sholeh secara langsung pada waktu menyelenggarakan forum komunikasi hubungan antarumat beragama.

Sumber data dalam penelitian ini adalah data primer dan data sekunder. Sumber data primer diperoleh dari hasil wawancara dan pengamatan terhadap Kiai Sholeh. Sedangkan sumber data sekuder diperoleh dari buku, dokumen, dan foto yang ada dipondok pesantren Ngalah.

\section{METODE PENGUMPULAN DATA}

Penelitian ini menggunakan metode wawancara mendalam, observasi, dan dokumentasi. Peneliti menggunakan wawancara mendalam dalam mengumpulkan informasi atau data karena peneliti membutuhkan jawaban yang lengkap dan mendalam, bila perlu tidak ada yang disembunyikan oleh nara sumber. Selanjutnya peneliti membedakan antara orang yang akan diwawancarai hanya sekali seperti santri dan orang yang ingin peneliti ketahui atau pahami yang akan diwawancarai beberapa kali seperti Kiai Sholeh. Observasi merupakan metode selanjutnya yang akan dilakukan oleh peneliti dalam mengamati interaksi Kiai Sholeh dengan elitagama lain. Metode dokumentasi digunakan peneliti untuk mendapatkan informasi yang mendukung analisis dan interpretasi data seperti sejarah Kiai Sholeh, foto-foto yang menginterpretasikan hubungan antarumat beragama, dan buku-buku karya pondok pesantren Ngalah yang mencerminkan pluralisme agama. Peneliti menggunakan teknik analisis data dengan model yang telah ditawarkan oleh Miles dan Huberman dalam Sugiyono yaitu aktifitas dalam analisis data yaitu: data reduction, data display, dan data conclusion drawing/verification [16].

\section{HASIL DAN PEMBAHASAN}

Menurut para teoretikus CMM, manusia mengorganisasikan makna dengan cara yang hierarkis [1]. Dari penelitian ini akan dijabarkan studi model CMM pada makna hubungan antarumat beragama perspektif Kiai Sholeh secara hierarki. Penelitian dalam studi konstruksi makna hubungan antarumat beragama dengan pendekatan model CMM akan didapatkan konstruksi sebagai berikut:

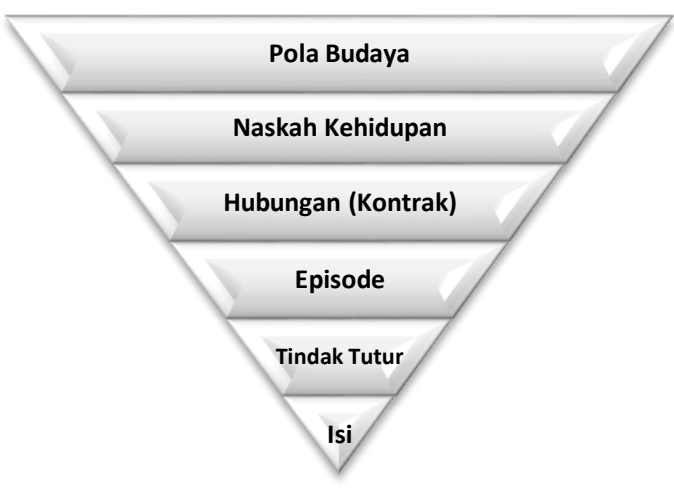

Gambar 1: Hierarki Makna

1. Isi

Menurut Pearce \& Cronen dalam West \& Turner level isi (content) merupakan langkah awal di mana data mentah dikonversikan menjadi makna. Pemaknaan level isi dalam penelitian Studi model CMM adalah makna hubungan antarumat beragama [1]. Kiai Sholeh memaknai hubungan ini dalam konteks pluralisme. Pluralisme menurut Kiai Sholeh adalah campur-campur maksudnya adalah Tuhan menciptakan manusia tidak hanya terdiri dari satu kelompok, suku, warna kulit, dan satu agama saja, tapi Tuhan menciptakan manusia berbeda-beda agar mereka bisa saling belajar, bergaul, dan membantu antara satu dan lainnya.

Kiai Sholeh mengatakan bahwa perbedaanperbedaan itu sebagai sebuah realitas yang pasti ada dimana saja. Sebagaimana pendapat Azyumardi Azra dalam Naim bahwa pluralisme diakui oleh islam dalam kerangka normatif dan historis. Sikap yang paling tepat adalah dengan mengembangkan sikap saling menghormati, toleran, dan menghargai pluralisme [17]. Begitu juga menurut Komarudin Hidayat dalam Naim bahwa pluralisme bukan merupakan kesesatan yang terkutuk, melainkan sebagiannya justru 
merupakan keharusan penjelmaan historis dari esensi agama yang bersifat esoterik. Pluralisme bukan berarti relativis yang tidak memiliki pendirian. Pluralisme lebih cenderung melihat perbedaan untuk senantiasa mencari, menggenggam, dan membela kebenaran yang diyakininya berdasarkan pengetahuan dan tradisi yang dimilikinya [17].

\section{Tindak Tutur}

Menurut Pearce dalam West \& Turner bahwa Tindak tutur adalah tindakan-tindakan yang kita lakukan dengan cara berbicara seperti: memuji, menghina, berjanji, mengancam, menyatakan, dan bertanya. Pearce juga mengatakan bahwa tindak tutur bukanlah benda, tindak tutur adalah konfigurasi dari logika makna dan tindakan dari percakapan, dan konfigurasi ini dibangun bersama [1]. Selanjutnya, proses tindak tutur dalam konteks makna hubungan antarumat beragama perspektif Kiai Sholeh dapat digambarkan sebagai berikut:

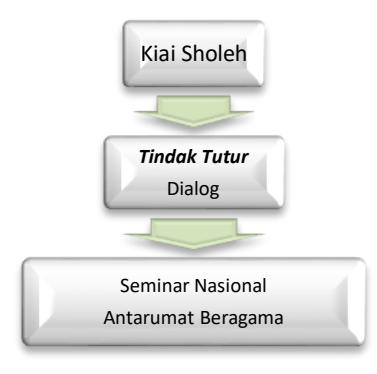

Gambar 2: Tindak Tutur

Berdasarkan konteks tindak tutur yang dihasilkan oleh Kiai Sholeh dari logika makna hubungan antarumat beragama adalah dialog antarumat beragama dengan konsep seminar nasional yang diselenggarakan pada tahun 2006 dan 2010 dengan tujuan agar supaya tidak terjadi perang antarumat beragama. Dari seminar ini terjadilah dialog antarumat beragama. Menurut Ign. Adam Suncoko dialog adalah tukar menukar informasi dan inspirasi dari orang di luar diri kita. Dalam konteks dialog antar umat beragama, kita sadar bahwa tidak ada suatu agama yang dapat secara keseluruhan menampung misteri llahi, ada nilai luhur disetiap agama yang dapat jadi nilai bersama. Dialog merupakan komunikasi yang akan saling memperkaya untuk mengenal sang misteri Agung, yakni suatu misteri kehidupan beragama sekaligus kehidupan kemasyarakatan.

Menurut Naim tujuan dari dialog adalah untuk membangun pemahaman dan saling pengertian, bukan untuk meraih kemenangan [17]. Dialog antarumat beragama yang diprakarsai oleh Kiai Sholeh membentuk pemahaman untuk menjaga kerukunan antarumat beragama yang berlandaskan NKRI, Pancasila, Bhinneka Tunggal Ika dan UUD 45. Hal ini sebagaimana dikemukakan oleh Hassan Hanafi, tujuan dialog adalah 1) terwujudnya landasan humanisme umum, 2) memodernisir agama ke satu titik pusat sasaran, yakni peranan dan arti agama, 3) meningkatkan keimanan, 4) dialektika yang memiliki ciri-ciri: pluralisme, pertukaran dan asal-usul keasliannya yang terjadi dalam masyarakat.

\section{Episode}

Menurut Pearce dan Cronen dalam West \& Turner bahwa episode mendiskripsikan konteks dimana orang bertindak. Pada level ini kita mulai melihat pengaruh dari konteks terhadap makna. Menurut Pearce dan Cronen untuk membahas episode dengan menginterpretasikan tindak tutur [1].

Selanjutnya, proses episode dalam konteks makna hubungan antarumat beragama perspektif Kiai Sholeh dapat digambarkan sebagai berikut:

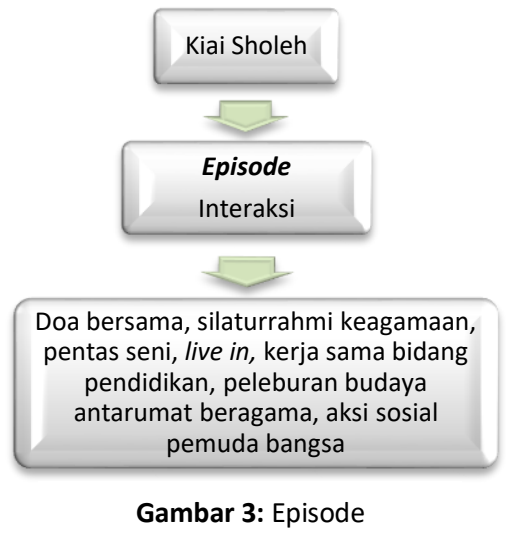

Tindakan Kiai Sholeh mengadakan seminar nasional antarumat beragama, sudah diinterpretasikan dengan konteks interaksi seperti:

\section{a) Doa bersama antarumat beragama}

Dalam rangka menciptakan kerukunan dan keharmonisan antarumat beragama Kiai Sholeh melakukan forum doa bersama. Kiai Sholeh menjelaskan bahwa Rosulullah juga pernah mendoakan non muslim. Kita sebagai umatnya seharusnya meneladani tindakan beliau. Sebagaimana menurut Sumbulah dan Nurjanah bahwa doa bersama dapat mengajarkan semua agama nilai-nilai universal, berupa kebaikan, kejujuran, dan keteladanan [8]. Sedangkan menurut Zainuddin bahwa tujuan dari doa bersama adalah untuk membangun spiritualitas dan moralitas, nilai-nilai bersama, dan mewujudkan kerukunan antarumat beragama. 
Doa bersama juga memiliki motif pragmatik, yaitu kepentingan bersama untuk memohon kepada Tuhan agar tercipta kedamaian dan ketentraman dalam hidup dan berkehidupan dalam NKRI [18].

b) Silaturrahmi keagamaan

Untuk menciptakan kerukunan antarumat beragama Kiai Sholeh menjalin silaturrahmi keagamaan kepada semua elit agama.Seperti silaturrahhmi yang pernah diterapkannya yaitu menghadiri tasyakuran dan peresmian di gereja Katolik ST. Theresia di Pandaan.

\section{c) Pentas seni}

Selain silaturrahmi, interaksi yang dikembangkan Kiai Sholeh untuk menciptakan kerukunan adalah pentas seni. Pentas seni yang digelar di pondok pesantren Ngalah dan dapat mempererat hubungan semua agama diantaranya: konser Iwan Fals yang dibuka oleh Kiai Sholeh bersama elit agama, pertunjukan barongsai yang bekerja sama dengan elit agama konghuchu, paduan suara antar umat beragama, wayang kulit, dan ludruk.

\section{d) Live In}

interaksi yang dilakukan Kiai Sholeh dengan elit agama lain diantaranya dengan mengadakan kerja sama melalui live in di pondok pesantren Ngalah Purwosari. Menurut Zainuddin Live in merupakan keterpanggilan dan kepedulian dalam membangun toleransi antarumat beragama dengan cara dialog dan tinggal bersama dalam waktu tertentu untuk mewujudkan kesatuan dan persatuan bangsa serta stabilitas nasional secara keseluruhan [18].

Kegiatan live in yang diadakan oleh pondok pesantren diantaranya :

1. Live In 100 Pendeta

Live in 100 pendeta merupakan bentuk keterpanggilan dan kepedulian Kiai Sholeh dan Pendeta Simon Filantropha, M.Th dari Gereja Kristen Indnonesia (GKI) untuk membangun toleransi antarumat beragama.

2. Live In Pelajar dari Australia

Tujuan live in pelajar dari Australia adalah untuk mempelajari bahasa Indonesia dan dapat belajar percakapan langsung dengan orang Indonesia. Selain itu tujuan mereka adalah untuk mengenal budaya Indonesia yang beragam dan untuk membuktikan bahwa Indonesia yang mayoritas beragama Islam penduduknya adalah negara yang damai tanpa ada kekerasan seperti yang diberitakan media massa.

e) Kerjasama dalam bidang pendidikan Selain live in untuk menciptakan kerukunan, Kiai Sholeh terbuka lebar untuk mengamalkan ilmunya kepada non muslim dan terbuka untuk mengadakan kerjasama. Kiai Sholeh mengajarkan kepada non muslim tentang indahnya kerukunan antaragama dan toleransi.

\section{f) Peleburan Budaya Antarumat Beragama}

Interaksi yang dilakukan Kiai Sholeh dengan elit agama lain juga dengan cara peleburan budaya. Menurut Zainuddin peleburan budaya ini merupakan ruang budaya yang mampu mencairkan suasana, mengikat tali persaudaraan dan membentuk hubungan kekeluargaan, bersahabat, dan menjauhkan kesenjangan antarumat beragama dan secara pragmatik memiliki kepentingan untuk "membangun persaudaraan sejati dan kerukunan bersama" [18]. Kiai Sholeh berusaha untuk melebur identitas yang sudah kental dimasing-masing agama guna untuk mencairkan suasana.

\section{g) Aksi Sosial Pemuda Bangsa}

Interaksi juga dikembangkan oleh Kiai Sholeh dan santri pondok pesantren Ngalah bersama pemuda GKJW. Seperti aksi sosial pemuda bangsa, aksi yang dijalankan dengan 2 kegiatan utama yaitu: layanan kesehatan gratis dan tanam pohon.

\section{Hubungan (Kontrak)}

Menurut Pearce dan Cronen dalam West \& Turner Level makna yang keempat adalah level hubungan (relationship), dimana dua orang menyadari potensi dan batasan mereka sebagai mitra dalam sebuah hubungan. Hubungan dapat dikatakan sebagai kontrak, dimana terdapat tuntunan dalam berperilaku [1].

Level hubungan menyatakan bahwa batasan-batasan hubungan dalam parameter tersebut diciptakan untuk tindakan dan perilaku, seperti ada batasan pada pembicaraan yang dianggap tabu. Menurut Pearce dan Cronen menyatakan bahwa batasan membedakan "kita dan mereka".

Selanjutnya, proses hubungan dalam konteks makna hubungan antarumat beragama perspektif Kiai Sholeh dapat digambarkan sebagai berikut:

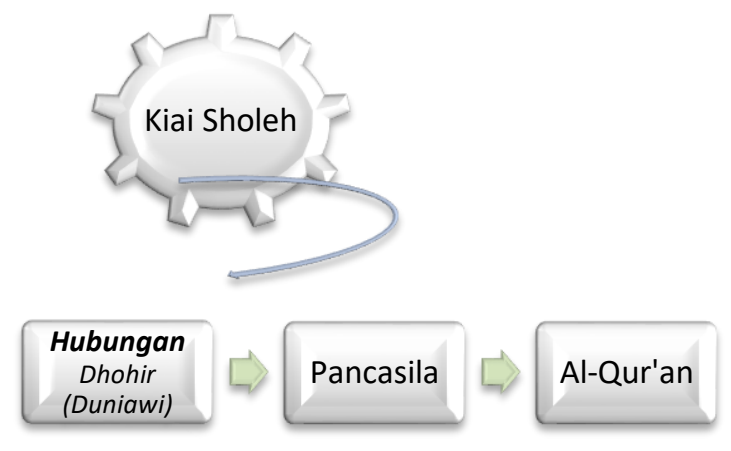

Gambar 4: Hubungan 
Kiai sholeh dalam menjalin hubungan dengan elit agama sebatas hubungan dhohir atau hubungan duniawi. Kiai Sholeh memakai rujukan at-Tafsir al-Munir karya Muhammad Nawawi alBantani yang isinya: berhubungan baik di dunia sebatas urusan yang nyata (hubungan dhohir) dalam artian hubungan duniawi saja, maka hal itu tidak dilarang. Hubungan yang telah dibangun berlandaskan pancasila sebagai dasar negara Indonesia. Landasan hukum pancasila adalah AlQuran.

\section{Naskah Kehidupan (Autobiografi)}

Kelompok-kelompok episode masa lalu dan masa kini disebut sebagai naskah kehidupan (life scripts).

Selanjutnya, proses naskah kehidupan dalam konteks makna hubungan antarumat beragama perspektif Kiai Sholeh dapat digambarkan sebagai berikut:

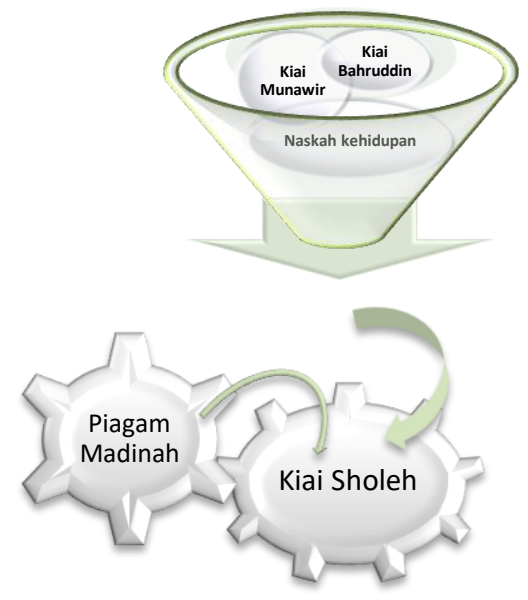

Gambar 5: Naskah Kehidupan

Berdasarkan gambar tersebut, konteks makna pluralisme Kiai Sholeh sangat dipengaruhi oleh kelompok episode masa lalu yaitu ayahnya sendiri Kiai Bahruddin dan gurunya Kiai Munawir. Selain itu, pemikiran pluralisme Kiai Sholeh juga dilatar belakangi dari pola kepemimpinan Nabi Muhammad yang berdasarkan piagam madinah. "Masyarakat Madani" adalah sebuah konsep kenegaraan yang merujuk pada pemerintah atau negara pada zaman Rasulallah di Madinah. Oleh sebab itu, setiap kali wacana konsep ideal sistem kenegaraan terutama dalam hubungannya dengan Islam diperbincangkan, maka orang akan selalu merujuk pada pemerintahan atau negara pada zaman Rasulullah di Madinah.

\section{Pola Budaya}

Pola budaya (cultural pattern) atau arketipe, dapat dideskripsikan sebagai "gambaran yang sangat luas dari susunan dunia dan hubungan (seseorang) dengan susunan tersebut" [1].

Menurut Cronen pola budaya berhubungan dengan nilai-nilai ini berkaitan dengan jenis kelamin, ras, kelas, dan identitas religius. Selanjutnya, proses pola budaya dalam konteks makna hubungan antarumat beragama perspektif Kiai Sholeh dapat digambarkan sebagai berikut:

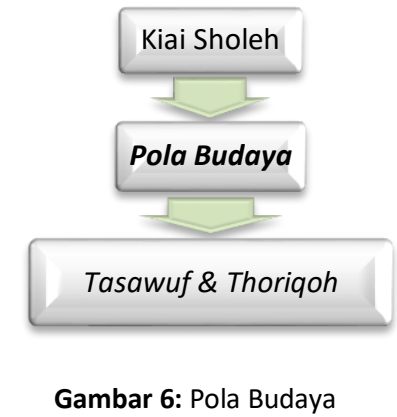

Berdasarkan konteks pola budaya, Kiai Sholeh menggambarkan dari susunan hubungan antarumat beragama dalam konteks tasawuf dan thoriqoh. Dalam teori CMM melalui hierarki makna dengan menggunakan piramida terbalik, konteks pola budaya merupakan konsep makro dari teori tersebut. Pola budaya yang sudah diterapkan oleh Kiai Sholeh dapat dilihat dari konteks tasawuf dan thoriqoh yang sudah diamalkan oleh beliau melalui jalan sufi dan 3 thoriqoh yaitu naqsyabandiyah, qodiriyah, dan syadiliyah yang merupakan tujuan akhir dari semua tindakan yang telah dilakukan oleh Kiai Sholeh selama ini. Menurut Kiai Sholeh tasawuf adalah seperti konsep sufi yang telah dikatakan oleh Syaikh Junaidi:

"Orang sufi itu bagaikan bumi yang mana segala sesuatu keburukan dia terima dengan selalu membalas dengan kebaikan. Orang sufi itu bagaikan bumi yang mana diatasnya berjalan segala sesuatu yang baik maupun yang buruk (semua diterimanya). Orang sufi itu bagaikan langit yang menaungi segala sesuatu yang ada dibawahnya, dan seperti air hujan yang menyirami segala sesuatu (yang baik maupun yang buruk)".

Dalam sabilus salikin dijelaskan definisi tasawuf, yaitu sebuah istilah yang menghimpun sepuluh makna:

1) Tidak terikat dengan semua yang ada di dunia sehingga tidak berlomba-lomba dalam mengerjakannya;

2) Selalu bersandar kepada Allah Swt.;

3) Gemar melakukan ibadah ketika sehat; 
4) Sabar kehilangan dunia (harta);

5) Cermat dan berhati-hati membedakan yang hak dan yang batil;

6) Sibuk dengan Allâh Swt. dan tidak sibuk dengan yang lain;

7) Melazimkan dzikir khafi (dzikir hati);

8) Merealisasikan rasa ikhlas ketika muncul godaan;

9) Tetap yakin ketika muncul keraguan; dan

10) Teguh kepada Allâh Swt. dalam semua keadaan [19].

Menurut Kiai Sholeh thoriqah adalah jalan yang dilalui oleh orang sufi dalam perjalanannya menuju Tuhan, dan digambarkan sebagai jalan yang berpangkal pada syari'ah. Konteks tasawuf dan thoriqoh merupakan konsep akhlak yang didalamnya terkandung nilai-nilai kebaikan untuk diterapkan oleh Kiai Sholeh dalam berhubungan baik kepada sesama muslim maupun berhubungan kepada nonmuslim.

\section{Hasil Pendekatan Model CMM Pada Hubungan Antarumat Beragama}

Hasil pendekatan CMM pada hubungan antarumat beragama dapat digambarkan secara keseluruhan dengan menggunakan hierarki makna sebagai berikut:

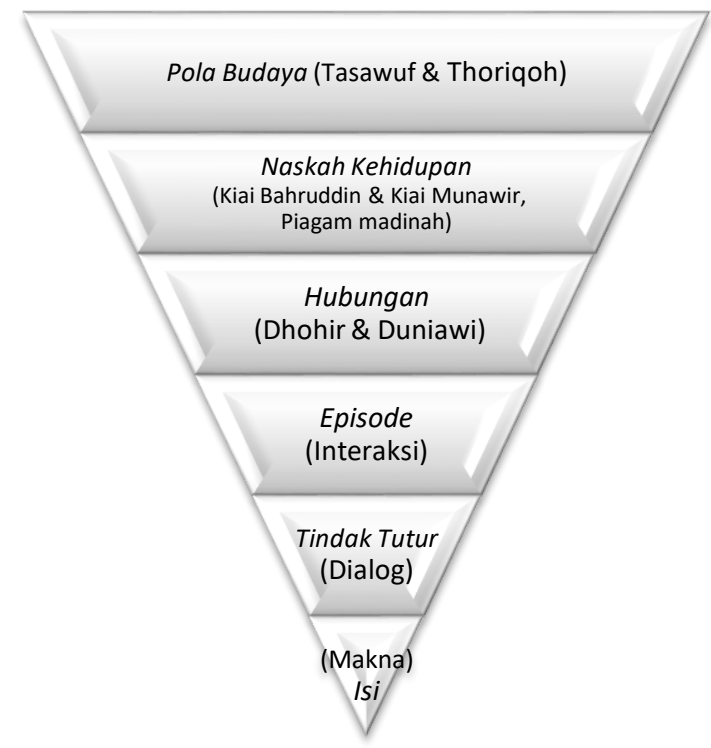

Gambar 7: Makna Hubungan antarumat beragama secara hierarki

Dalam konteks ini, makna hubungan antarumat beragama perspektif Kiai Sholeh dapat dilihat dalam tabel berikut:

Tabel 1. Konteks, konsep, dan formasi hubungan antarumat beragama perspektif Kiai Sholeh

\begin{tabular}{|c|c|c|}
\hline Konteks & Konsep & Formasi \\
\hline Isi & $\begin{array}{l}\text { Makna } \\
\text { Hubungan } \\
\text { antarumat } \\
\text { Beragama }\end{array}$ & $\begin{array}{c}\text { Tuhan menciptakan manusia } \\
\text { berbeda-beda agar mereka } \\
\text { bisa saling belajar, bergaul, } \\
\text { dan membantu antara satu } \\
\text { dan lainnyaserta mengakui } \\
\text { perbedaan itu sebagai } \\
\text { sebuah realitas }\end{array}$ \\
\hline $\begin{array}{l}\text { Tindak } \\
\text { Tutur }\end{array}$ & Dialog & Seminar Nasional \\
\hline Episode & Interaksi & $\begin{array}{l}\text { Doa bersama, silaturrahmi } \\
\text { keagamaan, pentas seni, live } \\
\text { in, kerja sama bidang } \\
\text { pendidikan, peleburan } \\
\text { budaya antarumat } \\
\text { beragama, aksi sosial } \\
\text { pemuda bangsa }\end{array}$ \\
\hline Hubungan & $\begin{array}{l}\text { Dhohir \& } \\
\text { duniawi }\end{array}$ & $\begin{array}{c}\text { Berlandaskan pancasila, } \\
\text { NKRI, } \\
\text { Bhinneka Tunggal Ika }\end{array}$ \\
\hline $\begin{array}{l}\text { Naskah } \\
\text { Kehidupan }\end{array}$ & $\begin{array}{l}\text { Ayah \& } \\
\text { Guru, } \\
\text { Piagam } \\
\text { Madinah }\end{array}$ & $\begin{array}{c}\text { Kiai Bahruddin \& Kiai } \\
\text { Munawir,Piagam Madinah }\end{array}$ \\
\hline $\begin{array}{l}\text { Pola } \\
\text { Budaya }\end{array}$ & $\begin{array}{l}\text { Tasawuf \& } \\
\text { Thoriqoh }\end{array}$ & $\begin{array}{l}\text { Konsep Sufi \& Thoriqoh } \\
\text { Naqsyabandiyah, Qodiriyah, } \\
\text { dan Syadiliyah yang } \\
\text { bermuara pada konsep } \\
\text { akhlaq dalam berhubungan } \\
\text { baik dengan sesama muslim } \\
\text { maupun non muslim }\end{array}$ \\
\hline
\end{tabular}

Dari tabel tersebut dapat dipahami bahwa makna Hubungan antarumat beragama perspektif Kiai Sholeh adalah Tuhan menciptakan manusia berbeda-beda agar mereka bisa saling belajar, bergaul, dan membantu antara satu dan lainnya dan mengakui perbedaan-perbedaan itu sebagai sebuah realitas. Kiai Sholeh mewujudkan konsep hubungan antarumat beragama dengan formasi dialog yang sudah diselenggarakannya dengan mengadakan seminar nasional kerukunan antarumat beragama. Interpretasi dari seminar nasional adalah interaksi Kiai Sholeh dengan nonmuslim seperti doa bersama, silaturrahmi keagamaan, pentas seni, live in, kerja sama bidang pendidikan, peleburan budaya antarumat beragama, dan aksi sosial pemuda bangsa.

Hubungan yang sudah dijalankan oleh Kiai Sholeh dengan non muslim sebatas hubungan dhohir dan duniawi bukan hubungan ukhrowi. Kiai Sholeh dalam menerapkan konsep hubungan 
antarumat beragama sangat dipengaruhi oleh ayahnya sendiri Kiai Bahruddin dan gurunya Kiai Munawir serta pemahaman Kiai Sholeh terhadap piagam madinah. Pola budaya yang telah diterapkan oleh Kiai Sholeh dalam hubungan antarumat beragama adalah konteks tasawuf dan thoriqoh yang sudah diamalkan oleh beliau melalui jalan sufi dan 3 thoriqoh yaitu naqsyabandiyah, qodiriyah, dan syadiliyah. Konteks tasawuf dan thoriqoh merupakan konsep akhlak yang didalamnya terkandung nilai-nilai kebaikan untuk diterapkan oleh Kiai Sholeh dalam berhubungan baik kepada sesama muslim maupun berhubungan kepada nonmuslim.

\section{KESIMPULAN}

Dari tabel tersebut dapat dipahami bahwa makna Hubungan antarumat beragama perspektif Kiai Sholeh adalah Tuhan menciptakan manusia berbeda-beda agar mereka bisa saling belajar, bergaul, dan membantu antara satu dan lainnya dan mengakui perbedaan-perbedaan itu sebagai sebuah realitas. Kiai Sholeh mewujudkan konsep hubungan antarumat beragama dengan formasi dialog yang sudah diselenggarakannya dengan mengadakan seminar nasional kerukunan antarumat beragama. Interpretasi dari seminar nasional adalah interaksi Kiai Sholeh dengan non muslim seperti doa bersama, silaturrahmi keagamaan, pentas seni, live in, kerja sama bidang pendidikan, peleburan budaya antarumat beragama, dan aksi sosial pemuda bangsa.

Hubungan yang sudah dijalankan oleh Kiai Sholeh dengan non muslim sebatas hubungan dhohir dan duniawi bukan hubungan ukhrowi. Kiai Sholeh menerapkan konsep hubungan antarumat beragama dipengaruhi oleh ayahnya sendiri Kiai Bahruddin dan gurunya Kiai Munawir serta pemahaman Kiai Sholeh terhadap piagam madinah. Pola budaya yang telah diterapkan oleh Kiai Sholeh dalam hubungan antarumat beragama adalah konteks tasawuf dan thoriqoh yang sudah diamalkan oleh beliau melalui jalan sufi dan 3 thoriqoh yaitu naqsyabandiyah, qodiriyah, dan syadiliyah. Pola budaya dalam konteks tasawuf dan thoriqoh merupakan tujuan akhir dari semua tindakan yang telah dilakukan oleh Kiai Sholeh selama ini. Konteks tersebut merupakan konsep akhlak yang didalamnya terkandung nilai-nilai kebaikan untuk diterapkan oleh Kiai Sholeh untuk berhubungan baik kepada sesama muslim maupun berhubungan kepada nonmuslim.

PROPOSISI

Penelitian ini menghasilkan teori CMM (Coordinated Management of Meaning) dalam konteks hubungan antarumat beragama yang berdasarkan pada 6 proposisi. Proposisi pertama, pemaknaan isi (content) tentang pesan hubungan antarumat beragama dalam perspektif komunikasi Islam. Proposisi kedua, pemaknaan tindak tutur (speech acts) tentang dialog antarumat beragama untuk menerapkan nilainilai budaya bangsa berlandaskan pancasila dan piagam madinah. Proposisi ketiga, pemaknaan episode (episode) tentang hubungan antarumat beragama dengan implementasi dalam bentuk aktivitas yang dapat membentuk hubungan kohesif. Proposisi keempat, pemaknaan hubungan (relationship) tentang hubungan antarumat beragama yang dicerminkan dalam hubungan dhohir dan dibatasi dengan hubungan batiniyah (aqidah). Proposisi kelima, pemaknaan naskah kehidupan (life scripts) tentang hubungan antarumat beragama yang diaplikasikan dalam tradisi pesantren dan konstitusi piagam madinah. Proposisi keenam, pemaknaan pola budaya (cultural pattern) tentang budaya ahlussunnah wal jamaah dan budaya kehidupan pesantren yang diwujudkan dengan tasawuf dan thoriqoh.

\section{SARAN}

Peneliti berharap penelitian ini ada yang melanjutkan dan menyarankan bagi peneliti selanjutnya untuk melakukan penelitian CMM pada tempat-tempat pengungsian, perbatasan negara, pertambangan, dan orang yang bertempat tinggal dan menetap pada etnis dan budaya yang berbeda.

\section{UCAPAN TERIMA KASIH}

Ucapan terima kasih penulis persembahkan kepada kedua orang tua dan keluarga besar khususnya Romo Kiai Sholeh Bahruddin yang telah memberi banyak inspirasi serta doa, dan motivasi; kepada dosen-dosen pembimbing Prof. Dr. Ir. Darsono Wisadirana, Dr. Suryadi, dan Dr. Antoni yang selalu meluangkan waktu untuk memberikan bimbingan dan masukan; Pihak-pihak dari Pondok Pesantren Ngalah yang telah memberi motivasi dan data-data yang berkaitan dengan jurnal ini; Serta semua pihak yang telah banyak membantu proses penyelesaian jurnal ini yang tidak dapat disebutkan satu-persatu.

\section{DAFTAR PUSTAKA}

\section{Daftar Pustaka dari Buku}

[1].West, Richard \& Turner, Lynn. (2014). Pengantar Teori Komunikasi: Analisis dan Aplikasi, Terjemah oleh Brian Marswendy. Jakarta: Salemba Humanika. 
[2]. Barge, Kevin. (2004). "Articulating CMM as a Practical Theory" Human Systems: The Journal of Systemic Consultation \& Management, 15: 187-198.

[3].Tan, Jasmine. (2012). " Gender and The Coordinated Management of Meaning in Women's Perception of Finance" ProQuest LLC.

[4]. Rahayu, Nuryani. (2010). "Teori Interaksi Simbolik dalam Kajian Komunikasi" Widyatama. Vol 19. No.1.

[5].Sobur, Alex. (2003). Semiotika Komunikasi, Bandung: Remaja Rosda Karya, h. 200.

[6].Mulyana, Deddy. (2001). Metodologi Penelitian Kualitatif. Bandung: PT Remaja Rosdakarya, h. 69.

[7]. Pondok Pesantren Ngalah, (2008). Buku Pedoman Santri Darut Taqwa Dalam Berbangsa dan Bernegara. Piagam Madinah. Pasuruan: Yudharta Advertaising Design.

[8].Sumbulah, Umi \& Nurjanah, (2013). Pluralisme Agama: Makna dan Lokalitas Pola Kerukunan Antarumat Beragama. Malang: UIN Maliki Press.

[9].Riyadi, M. Irfan dan Basuki, (2009). Membangun Inklusivisme Faham Keagamaan, Ponorogo : STAIN Ponorogo Press.

[10]. Laporan Kebebasan Beragama dan Toleransi di Indonesia, (2009), Lampu Merah Kebebasan Beragama. Jakarta: The Wahid Institute.

[11]. Hidayatullah.com, (2014). Diakses pada 24 Februari 2015 dari

(http://www.hidayatullah.com/berita/internasiona I/read/2014/10/18/31548/serangan-terhadapmuslim-meningkat-di-ustralia.html)

[12]. Wahid, Y., Sparringa, D., Siradj, S., Syam, N., Murtadlo, K., Buwono, S. et al. (2011). Dasar-Dasar multikultural teori dan praktek. Pasuruan: Yudharta Advertaising Design.

[13]. Bustomi, Amar; Irawan, Tosin; Kosirine, Yohanes; Suncoko, Adam; Filantropha, Simon; et al. (2010). Serumpun Bambu: Jalan menuju kerukunan sejati. Pasuruan: Yudharta Advertaising Design.

[14]. Neuman, Lawrence. (2013). Metodologi Penelitian Sosial: Pendekatan Kualitatif dan Kuantitatif Edisi 7. Terjemah oleh Edina $T$. Sofia. Jakarta: PT Indeks.

[15]. Kriyantono, Rachmat. (2010). Teknik Praktis Riset Komunikasi. Jakarta: Kencana.

[16]. Sugiyono. (2012). Metode Penelitian Kuantitatif, Kualitatif, dan R\&D. Bandung: Alfabeta.
[17]. Naim, Ngainun. (2014). Islam dan Pluralisme Agama. Yogyakarta: Aura Pustaka.

[18]. Zainuddin. (2010). Pluralisme Agama: Pergulatan Dialogis Islam-Kristen di Indonesia. Malang: UIN Maliki Press.

[19]. --------, (2012). Sabilus Salikin: Ensiklopedi Thoriqoh atau Tasawuf. Pasuruan: Yudharta Advertaising Design. 